Article

\title{
Catholic Mediation in the Basque Peace Process: Questioning the Transnational Dimension
}

\author{
Xabier Itçaina ${ }^{1,2}$ \\ 1 CNRS-Centre Emile Durkheim, Sciences Po Bordeaux, 11 allée Ausone, 33607 Pessac, France; \\ x.itcaina@sciencespobordeaux.fr \\ 2 GEZKI, University of the Basque Country, 20018 San Sebastian, Spain
}

Received: 30 March 2020; Accepted: 17 April 2020; Published: 27 April 2020

\begin{abstract}
The Basque conflict was one of the last ethnonationalist violent struggles in Western Europe, until the self-dissolution in 2018 of ETA (Euskadi ta Askatasuna, Basque Country and Freedom). The role played by some sectors of the Roman Catholic Church in the mediation efforts leading to this positive outcome has long been underestimated, as has the internal pluralism of the Church in this regard. This article specifically examines the transnational dimension of this mediation, including its symbolic aspect. The call to involve the Catholic institution transnationally was not limited to the tangible outcomes of mediation. The mere fact of involving transnational religious and non-religious actors represented a symbolic gain for the parties in the conflict struggling to impose their definitions of peace. Transnational mediation conveyed in itself explicit or implicit comparisons with other ethnonationalist conflicts, a comparison that constituted political resources for or, conversely, unacceptable constraints upon the actors involved.
\end{abstract}

Keywords: Basque conflict; nationalism; Catholic Church; Holy See; transnational mediation; conflict resolution

\section{Introduction}

The Basque conflict was one of the last ethnonationalist violent struggles in Western Europe, until the definitive ceasefire (2011), decommissioning (2017), and self-dissolution (2018) of the armed organization ETA (Euskadi ta Askatasuna, Basque Country and Freedom). The alleged definitive end of political violence has opened a two-fold debate in the Basque, Spanish, and French public spheres. The first dimension relates to the political and judicial consequences of the ending of the armed struggle, classically termed as "negative peace": decommissioning, rapprochement, release and reintegration of prisoners, and judicial treatment of victims. The second dimension deals with post-violence and the building, as a medium-term objective, of a "positive peace" (Brewer et al. 2011): work with victims and victim support groups; dealing with memory; dealing with the issues of hope, forgiveness, and reconciliation; and reintegration of protagonists. The memorial aspect holds a special importance in the Basque case with the opening of a new political arena around the competing narratives of the conflict over both its recent and its more ancient history (Tellidis 2018; Muro 2011). The post-2011 "batalla del relato" (battle of narratives), which is now taking place in social, media, political, academic, and fictional (Madina et al. 2018) fields opposes competing interpretations of the history and consequences of the conflict. Among other aspects, the role played by religion in general and by the Catholic Church in particular, both in the conflict and in its resolution, has now come back to the fore (Ontoso 2019). At first glance, this enduring politicization of religion, whether as part of the "problem" or of the "solution" to the political conflict, or both, is quite unexpected in the context of a very secularized society, such as Basque society. Religion is still deemed to play an important role in Basque society and politics, while churches are still empty and the proportion of priests per inhabitant has never been so low. Sociologists 
of religion have pinpointed the Basque Country as evidence of the third wave of secularization of Spain (Pérez-Agote 2012). Unlike the decatholicization or "mix and match" stage, which marked the second wave of secularization, secularization has entered into a phase of exculturation (Hervieu-Léger 2003), during which culture is gradually losing its Catholic roots. Moreover, in the Basque Country, this process has been exacerbated, according to Pérez-Agote (2006), by a kind of substitution of religion by politics and the national question as new social centralities. Yet, any intervention by the Church in Basque politics remains highly politicized.

This article aims to explore this paradoxical contrast between the perceptions of the Catholic Church as a relevant sociopolitical actor and the weakening of its social grip. This paradox is particularly intriguing in the role played by the Church in peacemaking. The relative leverage of Catholic actors in the peace process stemmed precisely from the secularization of politics and society in the Basque Country. The Church was seen as sufficiently detached from its former positions of power not to be suspected of hegemonistic ambitions, while also being perceived as a relevant social institution due to its territorial coverage, its expertise in peacemaking, and its presence in local welfare. This legitimacy is itself controversial due to the very institutional nature of the Church. As a memorial (Hervieu-Léger 1993; De Longcamp 2019) and a transnational institution, the Church embodies the memory of a longstanding relationship between Catholicism and Basque politics. Therefore, the Church's discourse and praxis on peace are highly exposed to politicization and publicization in times when historical narratives of the conflict are competing with each other.

The Catholic Church has also been perceived by Basque social and political actors as a legitimate actor in peacemaking due to its transnational influence. Basque political actors, in particular, seem to have perfectly understood the political ambivalence of the Church:

at the one hand, it remains a quintessentially conservative body with a hierarchical organization designed to preserve traditional theological teachings. This impulse produces conservative stances on sexual morality, abortion, and marriage, and puts the Church in alliance with other religious traditionalists, including Muslims. On the other hand, Catholic teaching on the dignity of the human person and the authenticity of the common good produce concern for the poor in the global economy and, specially [sic] in recent decades, advocacy of religious freedom, human rights, and democratic governance. (Hertzke 2016, p. 36).

In this respect, the transnational Catholic expertise on peacemaking, whether through the Holy See itself or through NGOs such as Sant'Egidio, has been regularly sought by political actors all over the world (Appleby et al. 2010). Building on Haynes' distinction between transnational and global civil society (Haynes 2012), Shani (2016) argues that transnational religious actors (in his case, Catholics and Sikhs) have the potential to collectively constitute an embryonic globalized transnational civil society as an alternative both to the Westphalian international order and to the secularized liberal model of global civil society. The Catholic Church would thus be part of a "post-secular" transnational civil society referring to "a network or coalition of non-state actors representing the interest of different transnational secular or religious communities, sharing a common interest in working together to overcome the challenges posed by globalization and the Westphalian states system" (Shani 2016, p. 300).

This potentially challenging role of the Church with respect to the Westphalian states system might be turned into an opportunity for "nations without states". This is especially the case if, as John Paul II did in his address to the United Nations General Assembly in 1995, the Catholic reference to human rights is interpreted as going together with a reference to peoples' and nations' rights. Such a perception, however, has been put to the test with the ambivalent transnational political role of the Church. Ferrari (2006) has framed the Catholic Church as being both a sovereign state and an NGO relying on soft power to achieve its aims, with a billion members all over the world. Barbato (2013) has emphasized the "multi-layered actorness" of the Holy See and of the Pope, who acts simultaneously as a head of state, as an international diplomat, and as the leader of a transnational religious community. In this sense, Barbato argues, the soft power of the Pope is based on the Holy See's ability to act in a multilevel game. As we will see with the Basque case, if in some circumstances the Church may act as 
a transnational actor fostering the values of solidarity, social justice, and peace in its interpretation of globalization, in other cases the Holy See can play a more conventional diplomatic role by acting as a "peer in a society of states" (Barbato 2013, p. 39), without necessarily challenging the existing state system.

In that respect, while the-itself controversial-role of the Church in the Basque Country in peacemaking has been scrutinized by various essays and from various standpoints (Placer Ugarte 1998; Bilbao Alberdi 2009; Cobos Romero 2018; Serrano Oceja 2001; Itçaina 2018), the transnational dimension of Catholic peacemaking in the conflict remains underexplored. Yet, the very institutional nature of the Catholic Church lies precisely in a hierarchical and social combination of its local and global dimensions. Without claiming to be exhaustive, in this essay, I engage with this transnational dimension. More specifically, in this paper, I examine the political work undertaken by the political institutions, parties, elites, and civil society organizations of the Basque Country since the mid-1990s in order to involve the transnational Church in conflict resolution and post-conflict rehabilitation. I do so by utilizing three bodies of literature: that on religion and peacemaking; that on Basque nationalism, political violence, and conflict resolution; and that on the sociology of political work and the making of public problems.

My main argument can be summarized as follows: the political result of this call to involve transnational Catholic institutions was not limited to the tangible outcomes (in terms of "success" or "failure") of mediation. Rather, the mere fact of involving transnational religious and non-religious actors represented a symbolic gain for the parties in the conflict struggling to impose their definitions of peace as a public problem. Thereupon, explicit or implicit comparisons with other ethnonationalist conflicts that have inevitably arisen from the appeal for transnational mediation have constituted either political resources for or, conversely, unacceptable constraints upon, the actors involved. The remainder of the article develops this argument in two stages. Section 2 focuses on the political work conducted, directly or indirectly, alongside the Holy See by the Basque autonomous government and by its main component, the Basque Nationalist Party (Partido Nacionalista Vasco, PNV), as part of its strategy of paradiplomacy. Section 3 shows that the call for transnational religious mediation was not monopolized by the Basque government or by the PNV and that it was performed by a wider array of Basque political parties and peace movements, thus involving different political and semantic uses of transnational comparisons. In my concluding remarks, I set out new hypotheses on the future of this plural relationship with transnational religious mediation in the context of post-violent Basque society.

In this article, I rely on qualitative research conducted among the Catholic organizations, peace groups, and political parties involved in the Basque conflict, on media analysis, and on original archive material regarding the relations between the Basque autonomous government and the Vatican authorities between 1996 and 2007. Additionally, a campaign of semi-directed interviews was conducted in the Spanish and French Basque Country. On the one hand, I made use of data collected in 1995 and in 2005-2006 with Cross-Border Coordination for Basque Country Priests (Euskal Herriko Apaizen Koordinakundea-EHAK), with the Franciscan monks at Arantzazu and Saint-Palais, with members of the Synod of Bayonne's Secretariat, and with Basque former priests and seminarians. I updated this research with a campaign of interviews carried out in 2012-2013 with the following personalities and organizations: Monsignor Uriarte, former Bishop of San Sebastián between 2000 and 2009; the vicar general of the Diocese of Bilbao; a theologian at the University of Deusto; an official at the Baketik (Peace) Centre at Arantzazu; Christian activists in the PNV; the former Delegate of the President of Euskadi for External Relations between 1990 and 2007; and the Socialist Party of the Basque Country-Basque Country Left (Partido Socialista de Euskadi_Euskadiko Ezkerra, PSE-EE), including a co-founder of the Cristianos en el socialismo (Christians in Socialism), the lay association Eutsi Berrituz (Hold Fast While Renewing) in San Sebastián, and the Fedea eta Kultura (Faith and Culture) Association in Bayonne. 


\section{The Expected Advocacy: The Holy See and the Paradiplomacy of the Basque Government}

\subsection{Informing and/or Involving Rome}

Even though most of the peace effort was performed by local civil society, the parties involved in the conflict also tried to involve transnational actors in conflict transformation, including religious actors. A first strategy consisted of Basque institutions and peace movements involving the Holy See itself. One of the most sustained efforts came from the Basque autonomous government. There were reasons for this strategy, starting with historical ones. Established in 1980 during the democratic transition, the Basque government was thereafter controlled, except between 2009 and 2012, by the PNV, either alone or in coalitions. Even though the party officially gave up its denominational identity when it was legalized in 1977, the PNV, itself one of the oldest political parties in Europe (founded in 1895), had its roots in Christian democracy and was one of the founding members of the International Christian Democracy (Gilmour 2005). Due to this legacy, the PNV and the Basque government continued to attach importance to their relations with the Catholic Church, at both the local and global scales. The relationship between this sector of Basque nationalism and Rome was influenced by the former connection between Basque nationalism and Catholicism but was also tainted with mutual distrust given the support of the Vatican for Franco's regime. Despite this ambivalent memory, after 1980, the Basque government carried out political work in order, at the very least, to inform the Holy See about the conflict and, at the most, to involve it in the peace process.

Formally speaking, this strategy did not produce much of a result. The end of the armed struggle in 2011 was a conjunction of many causes-in particular, the loss of social support for violence and internal changes in the independentist left strategy_including the peace work performed by the local church, but the Holy See probably did not play a crucial role here. Roman institutions remained cautious about the Basque question, and no official mediation by Vatican officers was performed, at least publicly, during the violent years. Among other causes, pressure from the Spanish government, state-level political parties, associations of victims, and the Spanish Catholic hierarchy itself, prevented any formal involvement of Rome. However, despite this apparent failure, the political work undertaken by representatives of the Basque government alongside the Holy See testified to an enduring political effort with multiple dimensions.

In that respect, the conceptualization of political work by Smith (2016) may be helpful. According to this approach, political work refers to the strategies undertaken by actors to maintain or to change institutions, and it encompasses three interrelated aspects: the making of public problems, the construction of policy instruments, and the legitimization of both actors and instruments. The politics of the Basque government with respect to the Vatican did not manage to, or perhaps did not even aim to, involve the Holy See in direct mediation for conflict resolution/transformation/amelioration (McCall 2013). Nevertheless, the two remaining dimensions were crucial ones. The Basque government strove to report its reading of the Basque situation-i.e., an alternative reading to both the narrative of the Spanish government and that of the Basque independentist left. By doing so, the Basque government and the PNV sought to appear as the "owners" of the Basque "public problem" (Gusfield 1981), and their representatives worked to convey their interpretation to the Vatican.

\subsection{Three-Pronged Political Work}

This strategy was particularly obvious in the 1990-2000s and was mainly structured around three main issues.

A first set of issues related to the institutional organization of the Church in the Basque Country: the appointment of bishops and the request for a territorial reorganization of the Church. As early as 1992, José Antonio Ardanza, then president of the Basque government, wrote to Cardinal Sodano, State Secretary of the Holy See, asking him for a meeting in order to comment on the appointment of bishops in the Basque Country. In 1996, the appointment of a non-Basque-speaking bishop in Bilbao (Mons. Blázquez) raised concerns among Basque center-right nationalists. The Basque government 
also repeatedly supported (for instance in 1996-1997) the demand for a unique ecclesiastical province gathering the Basque dioceses. The answer of the State Secretary of the Holy See was always an institutional one, insisting on the universal nature of the Church - "there is no Basque Church, but a universal one" - and on the fact that the territorial organization of the (Spanish) Basque Church was under the jurisdiction of the Spanish Episcopal Conference. Intervening in this first set of issues raised a problem of jurisdiction for the Basque government. To what extent should a regional government have its say on internal church affairs? The discreet interventions of the Basque government found a justification in the importance of the Church in Basque society, thus disentangling the secularization of society and the ongoing social presence of the Church, particularly in local welfare.

A second set of issues concerned information about the Basque political conflict. Here, the Basque government's main concern was informing the Holy See on a regular basis and transmitting its own reading of the situation. The challenge for the government consisted in finding transnational support for the third way it defended, between the anti-terrorist and repressive stance of the Spanish government and the implicit support for political violence from the Basque independentist left. The repeated informal meetings between representatives of the Basque government and Holy See officials were above all to maintain channels of information rather than formal attempts to involve the Holy See.

"Informing" the Holy See, however, was far from simple, because it implied gaining enough legitimacy to access its top bureaucracy. Recognition was never taken for granted, due to political pressures and diplomatic rules. The fact that the Vatican Secretariat for Relations with States could maintain informal discussions with the representatives of a regional government was not self-evident. On the other hand, maintaining relations with the Vatican made sense in the broader picture of the paradiplomacy developed by the Basque government (Totoricagüena 2005; Aldecoa and Keating 1999). Opening an informal channel of communication with a subject of international law such as the Holy See was a way for the Basque government to behave $a$ s a state while being a non-central government actor. Here, as elsewhere (Lecours and Moreno 2003), the link between stateless nationalism and paradiplomacy was conditioned by domestic and international opportunity structures.

Usually discreet and "contained" (Gilbert and Henry 2012), these exchanges of information could be publicized and politicized at critical junctures. In September 2000, the canonization of María Josefa del Corazón de Jesús Sancho de Guerra Maria, founder of the Servants of Jesus of Charity, gave rise to such a controversy. As the future saint was a native of the Spanish Basque Country (Vitoria, 1842-Bilbao, 1912), the ceremony brought to Rome a significant Basque delegation, including political leaders. Among them was Juan José Ibarretxe, at that time president of the Basque government. The lehendakari (president) took advantage of the situation and was received by Mons. Jean-Louis Tauran, then Secretary of Relations with States of the Holy See, a meeting that in itself raised an institutional issue:

"He [Tauran] had no obligation to receive Ibarretxe, since he was the Secretary of Relations with States of the Holy See. Then of course, one might consider that the lehendakari is State. Es Estado. España. He is part of the state. In the territory of the Basque Country, he is the representative of the government and of the Spanish state. We can consider it that way. But anyone who would interpret it strictly might say: no. He is not a representative of the state. Besides, there was a minister who was there. Mayor Oreja. So Mons. Tauran would have had a legitimate excuse to say no." ${ }^{11}$

Apart from this meeting, Ibarretxe took part, along with the delegation organized by the Spanish Embassy, in the ceremony of canonization presided by the Pope on 1 October 2000. The next day, Ibarretxe went to Florence and met with Vannino Chiti, State Secretary for the Presidency of the Italian Council of Ministers, and Claudio Martini, president of the Tuscany Region. After the meeting, Martini 
called on the European Union to "help in the process" leading to peace in the Basque Country. ${ }^{2}$ The Vatican meeting, for its part, caused controversy in the Spanish media surrounding the ambiguity of the "contribution" to pacification in the Basque Country proposed by the Holy See, though Ibarretxe himself had remained very cautious. He was reported to have given Mons. Tauran a "non-distorted" analysis of the situation in the Basque Country and to have handed him a copy of the peace plan that he had delivered to the Basque political parties. Ibarretxe thanked the Holy See for its offer, a "contribution which will be channeled through the work done by the Basque bishops". ${ }^{3}$

The subtle distinction between the Holy See's offer of a "contribution" rather than "mediation" led to diverging interpretations. The Spanish Church did not react officially, stating that should any mediation effort emanate from the Holy See, it would necessarily transit through the Spanish Catholic hierarchy. ${ }^{4}$ The Spanish government made it clear that there had not been any proposal of mediation in the conversation held by Mons. Tauran on this occasion with Jaime Mayor Oreja, then Spanish Minister of Home Affairs. ${ }^{5}$ Josep Piqué, Minister of Foreign Affairs, made it clear that the Holy See had limited itself to a "generic offer" of collaboration and that the Holy See could not act as an intermediary "between a democratic state and murderers". 6 The Spanish right (Popular Party, PP) and left (PSOE, Spanish Socialist Party) centralist parties released similar declarations, while the Basque center-right (PNV) and social-democrat (Eusko Alkartasuna-EA) parties welcomed what they perceived as a "proposal" from the Holy See. Given the controversy, the Holy See deemed it proper to clarify the issue by specifying that there was no question of mediation but instead "the contribution that the Catholic Church could continue to offer" in the search for a solution to the "terrorist" problem in the Basque Country. ${ }^{7}$

Beyond the controversies, the episode above highlights the symbolic sensitivity of the involvement of the Holy See in a domestic conflict. The mere fact that the Secretary of Relations with States of the Holy See had maintained separate conversations with a state minister and with the head of a regional government could be perceived as a symbolic gain for the Basque authorities. The interview that the Basque president was supposed to give on Radio Vatican was cancelled, as it was considered "inappropriate" by the State Secretary of the Holy See. Secondary questions of etiquette took on a symbolic meaning: Ibarretxe and Mayor Oreja were sitting side by side during the ceremony of canonization, an equal status, which was seen as problematic by observers. ${ }^{8}$ For the Basque leader, the domestic context necessitated such an additional legitimacy. The context in the Basque Country had become tense again since the end of ETA's 14-month ceasefire in December 1999. The week after the canonization, the Basque Parliament had to hold a debate on a confidence motion filed by the PP, with the support of PSOE, against Ibarretxe. The few words pronounced in Basque ${ }^{9}$ and in Spanish by the Pope during the ceremony also left room for diverging interpretations. The right-wing Spanish press saw this intervention as a clear condemnation of ETA and its supporters. ${ }^{10}$ The Basque media, meanwhile, stressed the call for peace and reconciliation in the papal message.

Similar debates took place after ETA's announcement of a ceasefire on 22 March 2006. On 3 April 2006, Monsignor Uriarte, then Bishop of San Sebastián, presented to the Vatican the efforts made by

\footnotetext{
Deia, 4 October 2000.

Deia, 3 October 2000.

"El Vaticano se ofrece para buscar una 'solución pacífica' en el País Vasco", El Mundo, 3 October 2000.

El País, 3 October 2000.

"El Vaticano asegura que no ha propuesto una mediación para lograr la paz en el País vasco", Diario Vasco, 4 October 2000. Ibid.

8 Additional problems of etiquette were reported by the Spanish ambassador to the Holy See in his memoirs (Abella y Ramallo 2006).

9 "May the model and the intermediation of saint María Josefa del Corazón de Jesús help the Basque Country in eradicating violence forever, and in turning the blessed land of Euskadi into a place for peaceful living together and fraternity, where the rights of all persons will be respected and where no innocent blood will ever be shed again" (Holy See press office, Bollettino, sala stampa della Santa Sede, $\mathrm{n} .{ }^{\circ} 568,1.10 .2000$, my translation from Basque).

10 La Razón, 2 October 2000.
} 
the Church of the Basque Country in favor of peace. Two days later, Pope Benedict XVI exhorted the congregation gathered in Saint Peter's Square "to pray that everybody will intensify their efforts for the consolidation of the horizons of peace that seem to be appearing in the Basque country and in Spain, and to overcome the obstacles that might appear" ${ }^{\prime 11}$. Despite a cautious attitude-promoting peace is not mediating in the conflict-the intervention of the Pope had a symbolical impact, as it helped put the Basque issue on the universalistic Catholic agenda. However, hope for a peaceful resolution of the conflict vanished when ETA resumed its violent campaign in December 2006.

A third set of issues referred to the historical memory of the longstanding relationship between the Basque political conflict and the Catholic Church. Revisiting the role of the Church and of the Holy See at the critical junctures of the Basque conflict acquired a new significance when memory issues again came to the fore in Spain in the 2000s (Leonisio et al. 2015, pp. 163-231). The PNV and the Basque government attached the utmost importance to the memory of the Spanish Civil War and its consequences, thus referring to the enduring contention about the divided positions of the Church. As evidenced by Molina (2011), the debate on the Basque Statute during the Spanish Second Republic (1931-1939) had become an exceptional political myth in contemporary Basque politics. According to current political narratives of Basque identity, the traditional will for self-government among the Basque people was expressed during those years in a wide-ranging demand for autonomy and identity. In contrast, Molina argues, the social complexity of the autonomy project was more related to religion than to ethnic conflict. Thus, this re-enacting of the past and the role of the Church held special significance in the context of the enduring political tensions of the 1990-2000s. In 1996, in the context of a debate about the Basque Church province, the Delegate of the President of Euskadi for External Relations took the initiative of sending Mons. Etchegaray, a French Basque cardinal who was at the core of the "hybrid mode of diplomatic agency" (Troy 2018) of the Holy See, ${ }^{12}$ a report by the Sabino Arana Foundation on the 1936 visit of the delegation of the Basque government to the Vatican. During this visit, Mons. Pizzardo, Secretary for Extraordinary Ecclesiastical Affairs, had asked President Aguirre to ally with the right-wing CEDA, ${ }^{13}$ a proposal that the Basque government eventually declined. In July 2002, the Delegate of the President of Euskadi sent Juan José Asenjo Pelegrina, General Secretary of the Spanish Episcopal Conference, a copy of the letter Imperativos de mi conciencia [Imperatives of my conscience] written in 1945 by Mons. Mugica, former bishop of Vitoria, explaining the positions of the Basque Church during the Civil War. Such a personal missive took on special meaning in 2002 in the midst of a controversy surrounding the pastoral card "Preparing peace", released by the bishops of the Basque Autonomous Community. The bishops' pastoral letter expressed reservations about the new Spanish electoral law on political parties, which had been designed by PP and PSOE to outlaw the Basque independentist party Batasuna. Even if it was not meant to establish any hazardous parallel between the Civil War and the 2002 situation, this historical reminder took on special signification in this context. Further episodes contributed to reactivating memorial issues. In 2007, the Holy See beatified 498 Spanish priests and clerics killed by the republicans during the Spanish Civil War. This decision aroused controversy in the Basque Country, in Spain, and abroad, ${ }_{1}^{14}$ against the backdrop of the approval of the Law on Historical Memory prepared by the socialist government in order to rehabilitate the victims of Franco. Basque nationalists lamented two major shortcomings. The first was the omission of the 16 Basque priests and thousands of republicans and democrats, among them many Catholics, who had been murdered by Franco's troops during the Civil War. The second referred to the

11 Quoted in Luis R. Aizpeolea, “El Papa apoyó el proceso de paz tras la mediación del obispo Uriarte ante el Vaticano", El País, 22 October 2006.

12 Roger Etchegaray had been president of the Pontifical Council Cor Unum between 1984 and 1995 and of the Pontifical Council for Justice and Peace between 1984 and 1998. Between 1979 and 2005, Etchegaray carried out several diplomatic missions on behalf of the Pope in Cuba, Rwanda, Jerusalem, China, and Iraq.

13 Confederación Española de Derechas Autónomas-Spanish Confederation of Autonomous Rightist Groups.

14 "Le Pape s'invite dans le débat sur la guerre civile espagnole", La Croix, 27 octobre 2007. 
support of the Spanish Church and of the Holy See for Franco's regime (Iztueta 1981) ${ }^{15}$. Again, this took on special significance in the context of the Spanish memorial debate.

To sum up, the political work led by the Basque government with the Holy See during the years of political violence presented three main characteristics. Firstly, it consisted above all in informal and discreet awareness-raising of the Holy See about the Basque government's view on Basque politics. Secondly, the efficiency of this work rested upon the key role of individual agency. In the 1990-2000s, the Delegate of the President of Euskadi for External Relations, himself a committed Catholic, played a pivotal role in establishing and maintaining, as personal and informal initiatives, this relationship with the Vatican Secretary of State. Thirdly, despite the significant presence of Basque priests and clerics in the Vatican hierarchy, this factor was not necessarily decisive in the Basque government's paradiplomacy efforts in Rome. Significantly, Mons. Etchegaray (1922-2019), while being central to Vatican diplomacy, remained cautious on the Basque question despite having his views regularly sought by Basque political and social actors. Following Smith (2016) concept of political work, we might conclude that despite its weak results in terms of new policy instruments on conflict resolution, the advocacy led by the Basque government toward the Holy See did result in the sharing of its problematization of the Basque conflict and in enhancing its own legitimacy as a substate and transnational political subject.

\section{Looking after Rome from the Left: Plural Mediations in a Deregulated Peace Market}

\subsection{A Functional Perception of Religious Intermediation}

The transnational mediation by the Catholic Church, and more broadly speaking by religious actors in the Basque conflict, was not monopolized by this first communication channel. Distinct sectors of the Basque political spectrum sought specific religious actors for their intermediation capacity. Even the Basque nationalist left, which had an anticlerical component, as well as many peace movements, were open to some form of intermediation by religious actors. Unlike the PNV, this call did not rely on a Christian democrat legacy or on a doctrinal convergence but, rather, on a functional view of religious actors as experts in peacemaking.

Transnational mediation was particularly necessary during ETA ceasefires and negotiation periods. This was the case when the Socialist Party came into power in Spain in March 2004 with more open positions with respect to negotiations on the Basque case. ${ }^{16}$ A two-pronged process then followed, the second round of which clearly staged the functional perception of religious intermediation by political actors. A first round of meetings, in Oslo and Geneva under the aegis of the Henri Dunant Centre, put ETA envoys in contact with the Spanish government. A second round of negotiations took place between three Basque political parties: Batasuna (at the time illegal in Spain), the Basque Socialist Party (PSE-EE-Partido Socialista de Euskadi-Euskadiko Ezkerra), and the PNV. This political roundtable comprised a dozen meetings in the Jesuit sanctuary of Loyola. Had an agreement been reached between the three parties, an original copy would have been given to the Vatican for safekeeping (Murua 2010, pp. 67, 133; Murua 2017). ${ }^{17}$

Unlike the PNV, this attitude was less expected of the two left-leaning parties. During the 2004-2005 conversations between Batasuna and PSE-EE, Basque leaders of both parties (respectively,

15 The Delegate of the President of Euskadi sent a letter in that sense to Mons. Dominique Mamberti, Secretary for Relations with States at the Holy See, 12 November 2007 (personal archive).

16 The process of opening lines of communication with ETA was endorsed by the Spanish Parliament on 17 May 2005.

17 According to Murua (2010), PSE-EE finally preferred to entrust it to the Society of Jesus. The parties' envoys were close to reaching an agreement on a text written in October 2006. This set out a scenario for an end to the crisis through a progressive alliance between Navarre and the Basque Autonomous Community, which would be subject to a referendum. However, the amendments introduced by Batasuna, followed by those of the PSE-EE, rendered the possibility for an agreement null and void. The ETA attack on Barajas Airport on 30 December 2006 sealed this failure, despite last-ditch meetings between the political and military wings in Geneva under the aegis of the Henri Dunant Centre in 2007. 
Arnaldo Otegi and Jesus Eguiguren) turned to the Church in order to facilitate contacts between ETA and the new government because of its transnational dimension. For Eguiguren, "the idea was to look for external mediation; and the Church was as an independent state; so if we wanted to talk with the Church, we had to go to Rome" (Eguiguren and Aizpeolea 2011, p. 32, my translation). Eguiguren met Etchegaray, but the French Basque cardinal kept the same distance as he had done before with the Basque government. He sent them back to his Basque counterparts and repeated that "the Holy See confirms, if things go well, but never baptizes" (Eguiguren and Aizpeolea 2011, p. 34, my translation). Given the stalemate in transnational mediation, Otegi and Eguiguren came back to the domestic Church. Interestingly, the Batasuna leader insisted on involving Mons. Uriarte, then bishop of San Sebastián, in the mediation, not because of his neutrality as a mediator but, on the contrary, because of his presumed proximity with the PNV and the Basque government, assuming that one would bring the other into the discussions. In this case, the legitimacy and credibility of the religious mediator did not stem from his position as an outsider but, as evidenced by Wehr and Lederach (1991) in Latin America, from his position as an insider, who could move peacemaking forward due to his profound understanding of the actors and the issues. Uriarte himself advised socialist and Batasuna leaders that local and direct mediation would probably be the most effective method. ${ }^{18}$

As noted by a major expert on the Basque conflict and peacemaking, himself a former leader of the Elkarri peace movement, the fact that the independentist left always maintained relations with the Church also revealed some kind of overestimation of the power of influence of the religious institution, especially on the transnational side:

Curiously enough, the abertzale [Basque nationalist] left has maintained a strong relation with Uriarte [bishop of San Sebastián]. Significant leaders Arnaldo Otegi, Rafa Diez and Rufi Etxebarria have always maintained regular relations with Uriarte. And I would say that this is still the case. This in the case of the abertzale left. In the case of the PNV, the syntony was greater. Which is logical. But all of them maintained contacts. Additionnally, the abertzale left has always considered that the Vatican has this important power, almost magical, international influence, and so on. For instance, he is now very old, but there was Mons. Etchegaray, the French Basque cardinal, who had been very active in his time. All this rendered the role of the church very attractive to the abertzale left. ${ }^{19}$

In its further attempts, the independentist left kept on searching for transnational mediators as a political strategy to transnationalize the conflict settlement. If religious elites were mobilized and/or accepted as mediators by the abertzale left, it was due to their expertise in peacemaking, but also, and maybe above all, in view of their potential contribution to this process of transnationalization of the cause. This strategy was particularly obvious between 2010 and 2018, in the various sequences of events leading to the end of ETA. As mentioned earlier, this process resulted from the combination of many factors: police repression, loss of popular support for violence, and a strategic change within the independentist left regarding political violence. The peacemaking efforts, and notably their transnational dimension, also played a significant role in this respect (Whitfield 2014).

\subsection{The Global Church and the Political Work around Transnational Comparison}

Even if it remains hazardous to measure the contribution of mediation to the end of violence, one can be more confident about the political uses of transnational mediation by Basque nationalism in general and by the independentist left in particular. The mere fact of framing the end of the armed struggle as a "peace process" involved an implicit and semantic comparison with other violent conflicts all over the world. Transnational mediation appeared to be a strategic resource for the nationalist

18 Taking into consideration that, on the global scale, the Basque conflict, as a low-intensity conflict, was probably seen as a minor issue by the Holy See (Mons. Uriarte. Author's personal interview, Bilbao, 2012).

19 Director of the Baketik peace center. Author's personal interview, Arantzazu, August 2012, translated from Basque. 
left struggling to frame the end of ETA as a step in a "peace process", i.e., one that implied a political contention and not merely a question of public order that would be solved through judicial and police measures (Zulaika and Murua 2017). This strategic use of comparison consisted first in involving the European institutions in the conflict settlement, with the Irish precedent in mind, thus updating an old strategy (Bourne 2003). The opposition of Spain restricted this involvement, which remained limited to the constitution of a support group for the Basque peace process in the European Parliament.

Given the lack of involvement of the EU and — at least publicly — of the states concerned, the actors of the Basque "peace process" turned to non-institutional forms of mediation, within and outside the EU. Zulaika and Murua (2017) labeled this role of international actors in the Basque process "virtual diplomacy". The announcement of the definitive end of its armed activities by ETA on 5 September 2010 was released in the wake of the Brussels Declaration in favor of the peace process. Presented to the European Parliament on 30 March 2010, the resolution was signed by a prestigious panel of international leaders, among them four Nobel Peace Prize winners (Frederick De Klerk, Desmond Tutu, John Hume, and Betty Williams), a former Irish Taoiseach (Albert Reynolds), a former general secretary of Interpol (R. Kendall), the Nelson Mandela Foundation, etc. On 20 October 2011, ETA announced the definitive end of its armed activities, two days after the International Peace Conference held at Aiete (San Sebastián) and organized by the citizen peace organization Lokarri, the Berghof Foundation, the Conciliation Resources, the Norwegian Peacebuilding Resource Center, the International Contact Group (ICG), and a team of top-tier international mediators. ${ }^{20}$ By September 2011, an International Verification Committee (CIV) had been constituted, composed of political leaders and experts engaged in conflict resolution in such diverse regions as South Africa, Northern Ireland, Sri Lanka, Kosovo, and Iraq. The CIV monitored the steps in the decommissioning of ETA through to the neutralization of the military arsenal of the organization on 8 April 2017 in the French Basque Country. The mobilization of such a range of international mediators reflected the quest for legitimacy of Basque peace groups, who aimed to circumvent the lack of involvement of the Spanish and, to a much lesser extent, French states. This strategy was also a way to stage an honorable way out for a weakened armed organization.

Zulaika and Murua (2017) proposed a thought-provoking reading of the involvement of the international community by using a theatrical metaphor. They argue that Aiete's "theatrical tolerance" (Zulaika and Murua 2017, p. 352) was particularly useful for the nationalist left "in that it turned the presence of the Spanish State into a sideshow, while it was the international community that acted as the ultimate witness" (Zulaika and Murua 2017, p. 352). Again, semantic debates were at the heart of this process: "indeed, even calling it a 'conflict' is a misnomer and an anathema for much of the Spanish elites and media." (ibid.). However, the attitude of the Spanish state varied according to the political color of its government: "Zapatero's government realized that the end of terrorism required international actors, and allowed for them while keeping a distance from them. This added the sense of 'theatre' and 'comedy' to the entire dialogue process that was officially denied while it was taking place" (Zulaika and Murua 2017, p. 352). The post-November 2011 PP government returned to harder positions with regard to the process and distanced itself from the confidential roadmap that had been drafted by the international facilitators.

Transnational religious actors were not at the core of this process. However, and together with the local church, some religious organizations and individuals had been involved in various attempts at mediation, before and after ETA's definitive ceasefire. The community of Sant'Egidio, known for its expertise in peacemaking (Holmsen 2018), had already attempted to mediate between ETA and the Spanish government in 1998 (Whitfield 2014, p. 93). Some attempts by the Society of Jesus were also reported in 1984 (Garaikoetxea 2002, pp. 179-80). The proximity of the Irish and Basque conflicts and the mutual strategic uses of comparison by activists (Espiau Idoiaga 2010; Alonso 2004; Bew et al. 2009; Bourne 2003) led a few religious mediators to circulate from one conflict to the other. In 2002, in a tense

20 Kofi Annan, Gro Harlem Bruntland, Bertie Ahern, Gerry Adams, Jonathan Powell, and Pierre Joxe. 
political context due to the outlawing of Batasuna in Spain, new discussions were opened between different Basque nationalist parties and organizations (moderate parties PNV and EA, ELA ${ }^{21}$ and $\mathrm{LAB}^{22}$ unions, Batasuna, cross-border association of municipalities Udalbiltza, abertzale lawyers). Alec Reid, a redemptorist Irish priest who had been involved in the Good Friday Agreement in Northern Ireland (Brewer et al. 2011), worked then as a mediator-broker in the Basque Country. Reid was initially asked by the Elkarri peace organization and by Joseba Segura, a priest from the diocese of Bilbao, to intervene in the Basque Country (Whitfield 2014, pp. 87, 230). Reid engaged in the Basque Country with a wide range of political actors and proposed a tactical ceasefire by ETA in order to reach a proposal of negotiation with the state. He was associated with various meetings and peace conferences held by Elkarri, together with Sant'Egidio, but also in direct intermediation between ETA and the post-2004 Spanish socialist government. ${ }^{23}$

Religious peace mediation, be it performed by local or transnational religious actors, was generally discreet in nature. Confidentiality was the condition for its efficiency. ${ }^{24}$ The most recent sequence around the ceasefire, decommissioning and dissolution of ETA was, on the contrary, signaled by a regular and highly publicized international mediation. The ICG, led by South African lawyer Brian Currin and then by the IVC led by Ram Malikkalingam, held meetings with representatives of the local church. In this case, transnational mediators, through the mediation of the Lokarri peace movement, asked for the presence of representatives of the Church as observers. Moreover, the presence of the Church was complicated by issues of representativeness and the lack of unity of the Church of the Basque Country. The point was highly sensitive, as underlined by the then Vicar General of the Diocese of Bilbao, who participated in the talks as an observer:

When they asked me: did you go there as a representative of the Church? No, I went there on my own, I am a member of the Church, I didn't go there in the name of the Church, but I had permission and support from my bishop. And we went there also because it was discreet. This became known later on, but on that day, there was no press or anything. We stood there, presentation, discussion, and nothing more. We took part in two of these meetings. I could not take part in the third one, I was in Rome. As a tourist, not as a mediator (laughs)! The forehead of social pastoral affairs [of the diocese of Bilbao] went. But, again, only for information. ${ }^{25}$

Representatives of the local clergy also participated as observers in the Aiete conference in October 2011. In this case however, representatives of the Church asked to be present as observers:

We were not on the first list. The list was made up of political parties, unions, some associations from here [the Basque Autonomous Community], from the French Basque Country, from Navarra. But we were not included. Once I was made aware of that, I told Paul [Rios, Lokarri]: we are ready to be there. In the wake of the work done by the church, of what we did in Bilbao. ( ... ) And they invited us. Now, in Aiete, I didn't say anything. I stood there. There was a small issue there: of course, we are the church of Biscaye. I told the bishop: if I have to go to Aiete, you must inform the bishop of San Sebastian. And the bishop of Vitoria as well, even though it is taking place in San Sebastian. The bishop of Vitoria had

21 Eusko Langileen Alkartasuna-Basque Workers Solidarity.

22 Langile Abertzaleen Batzordeak-Patriot Workers Union.

23 T. Whitfield observes that, beyond these direct contacts, some of them through the good offices of the British government, Reid was credited with encouraging the idea of dialogue. However, this mediation also reached its limits: Reid "did not speak Spanish, and his knowledge of the political situation was strongly influenced both by Northern Ireland and what even some within Batasuna would recognize as a degree of wishful thinking about the intentions of ETA" (Whitfield 2014, p. 142). On Reid's role, see also Eguiguren and Aizpeolea (2011, pp. 36, 242) and Alonso (2004, pp. 702-4).

24 In that respect, the publicization by the Spanish Ministry of the Interior of the mediation by Mons. Uriarte, then bishop of Zamora, during the ETA 1998-1999 ceasefire, was interpreted as one of the causes of the failure of the process (Eguiguren and Aizpeolea 2011, p. 35).

25 Vicar General of the Diocese of Bilbao. Author's personal interview. Bilbao, June 2012. Translated from Basque. 
no objection. And we came across the bishop of San Sebastian in the airport, in Paris or somewhere, and we told him that I would be there, since we wanted him to be aware. Then it was released in the press, that I had been there and all the rest ( . . ) well, as an observer. The Vatican also has observers in the UN. But I didn't say anything in Aiete. In informal discussions yes, but not during the conference. No evaluation, no opinion. Of course, there was some kind of official stance, but more from our diocese, from our bishop, not as a representative. They [the bishops] agreed on my presence, but nothing more. There remains, of course, another problem: there is no unified voice at the head of the Basque church. ${ }^{26}$

Inevitably, any presence of representatives of the Basque Church in these arenas raised issues related to the lack of unity of the Basque Church and to its internal divides. ${ }^{27}$ Resorting to transnational religious mediators was a way to avoid this difficulty. By contrast, the presence of international religious leaders among peacemakers was highly publicized during this last sequence of events. On 8 April 2017, many observers were surprised to see, among the figures gathered to witness the disarmament of ETA in Bayonne, Matteo Zuppi, the Archbishop of Bologna and former ecclesial assistant of the Sant'Egidio community, and Harold Good, an Irish Methodist minister who had been involved in the disarmament of the Irish Republican Army (Brewer et al. 2011). The list of locations of ETA's weapons caches was disclosed to these mediators. Their presence, however, was far from unanimously praised by the French and Spanish Basque diocesan authorities, in a further illustration of the internal pluralism of the Basque Church. ${ }^{28}$ The complex nature of the religious institutions made a multilevel presence in peacemaking possible but at the same time aroused tensions within the institutional apparatus of the Church.

\section{Concluding Remarks: Changing Transnational Religious Mediations in a Post-Violent Basque Country}

This article has sought to demonstrate that the involvement of transnational Catholic institutions in peacemaking in the Basque case should not be assessed only through its tangible outcomes. The strategies of Basque actors involved in the process followed symbolic and semantic aims as well as operational ends in terms of intermediation. Involving transnational secular and religious actors was a way for the parties in the conflict to impose their views on peace and on implicit comparisons with other ethnonationalist conflicts that were resolved by transnational mediation. In that respect, this article has distinguished the transnational, indirect, and informal political work conducted by the Basque regional government alongside the hierarchy of the transnational Catholic Church, from the work performed by other Basque political parties and peace movements. In the post-ETA scenario, the end of political violence in the Basque Country also put an end to the role of the Church as a backchannel of communication. Once the "negative peace" had been reached with the end of armed violence, the process entered a new stage consisting in building a "positive peace", dealing with the problems of post-violence, with victims, and with memory and reconciliation (Brewer et al. 2011, p. 40). On these issues, the local church, probably more than its transnational counterpart, would have its say, alongside the secular peace movements, political parties, and civil society organizations.

Nonetheless, the new political scenario did not put an end to relations between the transnational Church and the Basque political, institutional, and social actors. The Basque government, in particular, maintained its old relations with the Holy See but redirected the political work of mediation towards new emergencies, notably the post-2015 displaced persons and refugee crisis. In January 2017, Iñigo Urkullu, President of the Basque government, presented to Mons. Pietro Parolin, State Secretary of

26 Ibid.

27 In a previous work, I proposed to identify at least four positions within the Church of the Basque Country toward the conflict resolution: legalist, soft legalist, alternative, and deliberative (anonymized, chapter 6).

28 M. Malzac, "Le rôle de l'Eglise dans le désarmement de l'ETA", La Croix, 11 April 2018. 
the Holy See, the 2017-2020 Living Together and Human Rights plan (Plan de Convivencia y Derechos Humanos) of the Basque government. The Plan, which resulted from the PNV-PSE governing agreement signed in 2016, no longer gave priority to the end of ETA terrorism but, rather, to the refugee crisis in Europe. ${ }^{29}$ By doing so, the government, which had been a pioneer in social policies since its inception, put pressure on the Spanish government to show greater involvement in assistance to refugees. Presenting this plan to the Vatican took on a double meaning. First, it made sense in the traditional paradiplomacy of the Basque government. In substance, the communication channel with the Holy See was facilitated by the social sensitivity of Pope Francis. Urkullu also met Jesuits and Sant'Egidio, two Catholic bodies that had been involved in the peacemaking effort in the Basque conflict and that were now on the frontline of the refugee and migrant crisis. ${ }^{30}$ In August 2019, the lehendakari presented before the Holy See the "Share" proposal, related to refugees and migrants in very vulnerable situations. "Share" was a proposal put forward by various European substate governments ${ }^{31}$ and transmitted to EU authorities. It followed previous initiatives, such as humanitarian corridors, conducted by the Basque government in collaboration with civil society organizations, among them those related to the social branches of the Church. ${ }^{32}$ In a firmly secularized society, such as that of the Basque Country in the 21st century, one emergency was progressively replaced by another, but local and global religious actors kept their mediating role in a pluralistic civil society.

Funding: Part of this research was funded by the Marie Curie Fellowship of the European Commission, which allowed a 24-month stay at the European University Institute in Florence in 2012-2013.

Acknowledgments: The author acknowledges Jeff Haynes for his invitation, Andy Smith and the two anonymous reviewers for their comments and suggestions, all the persons who agreed to be interviewed, Jose María Muñoa for providing access to his personal archive, La Maison de la Traduction and the Editorial office of Religions for the linguistic revision of this article.

Conflicts of Interest: The author declares no conflict of interest.

\section{References}

Abella y Ramallo, Carlos. 2006. Memorias Confesables de un Embajador en el Vaticano. Madrid: Libros Libres.

Aldecoa, Francisco, and Michael Keating. 1999. Paradiplomacy in Action: The Foreign Relations of Subnational Governments. London: Frank Cass Publishers.

Alonso, Rogelio. 2004. Pathways out of terrorism in Northern Ireland and the Basque Country: The Misrepresentation of the Irish model. Terrorism and Political Violence 16: 695-713. [CrossRef]

Appleby, Scott, Robert J. Schreiter, and Gerard F. Powers, eds. 2010. Peacebuilding. Catholic Theology, Ethics, and Praxis. New York: Orbis Books.

Barbato, Mariano. 2013. A State, a Diplomat, and a Transnational Church: The Multi-layered Actorness of the Holy See. Perspectives, Review of International Affairs 21: 27-48.

Bew, John, Martin Frampton, and Iñigo Gurruchaga. 2009. Talking to Terrorists. Making Peace in Northern Ireland and in the Basque Country. London: Hurst \& Company.

Bilbao Alberdi, Galo. 2009. Sacrificadas a los Ídolos. Las Víctimas del Terrorismo en el Discurso de los Obispos Vasconavarros (1968-2006). Bilbao: Instituto Diocesano de Teología y Pastoral, Desclée de Brouwer.

29 Aizpeolea L. R., “Urkullu busca la interlocución con el Vaticano. El Gobierno vasco prioriza en la Santa Sede el reto de los refugiados sobre el final de ETA", El País, 30 January 2017.

30 In December 2018, Sant'Egidio, together with two other bodies working with refugees (Salvamento marítimo Humanitario, Zaporeak-Sabores solidarios) had been awarded the René Cassin Human Rights Prize given by the lehendakari.

31 In August 2019: Basque Autonomous Community, Navarra, Canaries, Navarra, Catalonia, Melilla, the French Basque intermunicipality community, Nouvelle-Aquitaine, Attica.

32 Acnur, Cear-Euskadi, Cruz Roja, Caritas, Servicio Jesuita al Refugiado, etc. (Eusko Jaurlaritza-Gobierno Vasco, "El Lehendakari viajará a Roma para presentar en el Vaticano la Propuesta Share en relación con las personas refugiadas y migrantes en situación de mayor vulnerabilidad", 21 August 2019. //www.euskadi.eus/gobierno-vasco/-/noticia/2019/el-lehendakari-viajara-a-roma-para-presentar-en-el-vaticano-lapropuesta-share-en-relacion-con-las-personas-refugiadas-y-migrantes-en-situacion-de-mayor-vulnerabilidad/, Accessed 3 February 2020). 
Bourne, Angela K. 2003. European integration and conflict resolution in the Basque Country, Northern Ireland and Cyprus. Perspectives on European Politics and Society 4: 391-415. [CrossRef]

Brewer, John D., Gareth I. Higgins, and Francis Teeney. 2011. Religion, Civil Society, and Peace in Northern Ireland. Oxford: Oxford University Press.

Cobos Romero, J. 2018. The role of the catholic church and religion in the basque conflict. Paper presented at Religion and Humanitarian Action, Uppsala, Sweden, May 7; Available online: https://www.researchgate.net/ publication/332142748_The_role_of_the_Catholic_Church_and_religion_in_the_Basque_conflict (accessed on 1 February 2020).

De Longcamp, Gonzague. 2019. L'Eglise communauté de mémoire. Nouvelle Revue Théologique 141: 22-35. [CrossRef]

Eguiguren, Jesús, and Luis Rodríguez Aizpeolea. 2011. ETA. Las Claves de la Paz. Madrid: Aguilar.

Espiau Idoiaga, Gorka. 2010. The Peace Process in the Basque Country and in Northern Ireland: A Comparative Approach. ICIP Working Paper 3. Barcelona, Spain: Institut Català Internacional per la pau.

Ferrari, Lisa. 2006. The Vatican as a Transnational Actor. In The Catholic Church and the Nation-State. Comparative Perspectives. Edited by Paul Christopher Manuel, Lawrence C. Reardon and Clyde Wilcox. Washington: Georgetown University Press, pp. 33-45.

Garaikoetxea, Carlos. 2002. Euskadi: La Transición Inacabada. Memorias Políticas. Barcelona: Planeta.

Gilbert, Claude, and Emmanuel Henry. 2012. La définition des problèmes publics: Entre publicité et discrétion. Revue Française de Sociologie 531: 39-55. [CrossRef]

Gilmour, John. 2005. Losing its soul: The changing role of Christian democracy in the development of Spain's new Right. South European Society and Politics 10: 411-31. [CrossRef]

Gusfield, Joseph. 1981. The Culture of Public Problems: Drinking-Driving and the Symbolic Order. Chicago: The University of Chicago Press.

Haynes, Jeff. 2012. Religious Transnational Actors and Soft Power. Surrey: Ashgate.

Hertzke, Allen D. 2016. The Catholic Church and Catholicism in global politics. In Routledge Handbook on Religion and Politics, 2nd ed. Edited by Jeff Haynes. London and New York: Routledge, pp. 36-54.

Hervieu-Léger, Danièle. 1993. La Religion Pour Mémoire. Paris: Cerf.

Hervieu-Léger, Danièle. 2003. Catholicisme, la fin d'un Monde. Paris: Bayard.

Holmsen, Jenny. 2018. Believe It or Not. The New Face of Religion in International Affairs: A Case-Study of Sant'Egidio. Ph.D. thesis, European University Institute, Florence, Italy.

Itçaina, Xabier. 2018. Catholic Mediations in Southern Europe. The Invisible Politics of Religion. London and New York: Routledge.

Iztueta, Paulo. 1981. Sociología del Fenómeno Contestatorio del Clero Vasco: 1940-1975. Donotia: Elkar.

Lecours, André, and Luis Moreno. 2003. Paradiplomacy and stateless nations: A reference to the Basque Country. In The Conditions of Diversity in Multinational Democracies. Edited by Alain G. Gagnon, Montserrat Guibernau and François Rocher. Montreal: The Institute for Research on Public Policy, pp. 267-92.

Leonisio, Rafael, Fernando Molina, and Diego Muro, eds. 2015. ETA Terrorist's Campaigns: From Violence to Politics. London and New York: Routledge.

Madina, Irene, Galo Bilbao, and Angela Bermudez. 2018. Recognizing victims of political violence: Basque literary narratives as an ethical tool. Studies in Conflict and Terrorism, 1-17. [CrossRef]

McCall, Cathal. 2013. European Union cross-border cooperation and conflict amelioration. Space and Polity 17: 197-216. [CrossRef]

Molina, Fernando. 2011. The reign of Christ over the nation: The Basque question in the Spanish Republic, 1931-1936. National Identities 13: 17-33. [CrossRef]

Muro, Diego. 2011. Ethnicity and Violence. The Case of Radical Basque Nationalism. London and New York: Routledge.

Murua, Imanol. 2010. Loiolako hegiak. San Sebastián and Bayonne: Elkar.

Murua, Imanol. 2017. Ending ETA's Armed Campaign. How and Why the Basque Armed Group Abandoned Violence. London and New York: Routledge.

Ontoso, Pedro. 2019. Con la Biblia y la Parabellum: Cuando la Iglesia Vasca Ponía una Vela a Dios y otra al Diablo. Madrid: Peninsula.

Pérez-Agote, Alfonso. 2006. The Social Roots of Basque Nationalism. Reno: University of Nevada Press.

Pérez-Agote, Alfonso. 2012. Les trois logiques de la religion en Espagne. In Catholicisme en Tensions. Edited by Céline Béraud, Frédéric Gugelot and Isabelle Saint-Martin. Paris: Éd. de l’EHESS, pp. 37-49. 
Placer Ugarte, Felix. 1998. Creer en Euskal Herria: La Experiencia Creyente de las Comunidades Cristianas Populares y de la Coordinadora de Sacerdotes de Euskal Herria, 1976-1996. Bilbao: Herria 2000 Eliza.

Serrano Oceja, José Francisco, ed. 2001. La Iglesia Frente al Terrorismo de ETA. Madrid: Biblioteca Autores Cristianos. Shani, Giorgio. 2016. Transnational religious actors and international relations. In Routledge Handbook on Religion and Politics, 2nd ed. Edited by Jeff Haynes. London and New York: Routledge, pp. 299-313.

Smith, Andy. 2016. The Politics of Economic Activity. Oxford: Oxford University Press.

Tellidis, Ioannis. 2018. Peacebuilding beyond terrorism? Revisiting the narratives of the Basque conflict. Studies in Conflict and Terrorism, 1-19. [CrossRef]

Totoricagüena, Gloria. 2005. Diasporas as non-central governmental actors in foreign policy: The trajectory of Basque paradiplomacy. Nationalism and Ethnic Politics 11: 265-87. [CrossRef]

Troy, Jodok. 2018. The Pope's own hand oustretched: Holy See diplomacy as a hybrid mode of diplomatic agency. The British Journal of Politics and International Relations 20: 521-39. [CrossRef] [PubMed]

Wehr, Paul, and John Paul Lederach. 1991. Mediating conflict in Central America. Journal of Peace Research 28: 85-98. [CrossRef]

Whitfield, Teresa. 2014. Endgame for ETA. Elusive Peace in the Basque Country. New York: Oxford University Press. Zulaika, Joseba, and Iñaki Murua. 2017. How terrorism ends-And does not end: The Basque case. Critical Studies on Terrorism 2: 338-56. [CrossRef]

(C) 2020 by the author. Licensee MDPI, Basel, Switzerland. This article is an open access article distributed under the terms and conditions of the Creative Commons Attribution (CC BY) license (http://creativecommons.org/licenses/by/4.0/). 